\title{
Diagnosis, Rehabilitation and Preventive Strategies for Pudendal Neuropathy in Cyclists, A Systematic Review
}

\author{
Rita Chiaramonte $^{1, *(\mathbb{D}}$, Piero Pavone ${ }^{2}$ and Michele Vecchio ${ }^{1,3, *}$ \\ 1 Department of Biomedical and Biotechnological Sciences, Section of Pharmacology, University of Catania, \\ 95123 Catania, Italy \\ 2 Department of Clinical and Experimental Medicine, University Hospital "Policlinico-San Marco", \\ 95123 Catania, Italy; ppavone@unict.it \\ 3 Rehabilitation Unit, "AOU Policlinico G.Rodolico", 95123 Catania, Italy \\ * Correspondence: ritachiaramd@gmail.com (R.C.); michele.vecchio@unict.it (M.V.); \\ Tel.: +39-(095)3782703 (M.V.); Fax: +39-(095)7315384 (R.C.)
}

check for updates

Citation: Chiaramonte, R.; Pavone,

P.; Vecchio, M. Diagnosis,

Rehabilitation and Preventive Strategies for Pudendal Neuropathy in Cyclists, A Systematic Review. J. Funct. Morphol. Kinesiol. 2021, 6, 42. https://doi.org/10.3390/jfmk6020042

Academic Editor: Milos Ljubisavljevic

Received: 12 April 2021

Accepted: 7 May 2021

Published: 10 May 2021

Publisher's Note: MDPI stays neutral with regard to jurisdictional claims in published maps and institutional affiliations.

Copyright: (c) 2021 by the authors. Licensee MDPI, Basel, Switzerland. This article is an open access article distributed under the terms and conditions of the Creative Commons Attribution (CC BY) license (https:// creativecommons.org/licenses/by/ $4.0 /)$.

\begin{abstract}
This systematic review aims to provide an overview of the diagnostic methods, preventive strategies, and therapeutic approaches for cyclists suffering from pudendal neuropathy. The study defines a guide in delineating a diagnostic and therapeutic protocol using the best current strategies. Pubmed, EMBASE, the Cochrane Library, and Scopus Web of Science were searched for the terms: "Bicycling" OR "Bike" OR "Cyclists" AND "Neuropathy" OR "Pudendal Nerve" OR "Pudendal Neuralgia" OR "Perineum". The database search identified 14,602 articles. After the titles and abstracts were screened, two independent reviewers analyzed 41 full texts. A total of 15 articles were considered eligible for inclusion. Methodology and results of the study were critically appraised in conformity with PRISMA guidelines and PICOS criteria. Fifteen articles were included in the systematic review and were used to describe the main methods used for measuring the severity of pudendal neuropathy and the preventive and therapeutic strategies for nerve impairment. Future research should determine the validity and the effectiveness of diagnostic and therapeutic strategies, their cost-effectiveness, and the adherences of the sportsmen to the treatment.
\end{abstract}

Keywords: bicycling; pudendal neuralgia; rehabilitation; systematic review

\section{Introduction}

Cyclists are particularly prone to trauma, infection, tumor, injury, and microtrauma related to their sport [1]. Cavernosal and dorsal arteries and pudendal nerve could be injured in many conditions, such as compression between the saddle and pubic bones or pubic symphysis during cycling or within the Alcock canal medial to the ischial rami [2,3].

While cycling, the body weight on the seat could compress nerves, vessels, or both. Repeated trauma to the perineum, prostatic disease in men, and pelvic pathology in females can favor the onset of the disorder [4,5]. According to Silbert et al. [5], the compression of the pudendal nerve could be related to the forward-leaning posture that presses perineum anteriorly to the ischial spine. According to Andersen and Bovim [6], if ischemia of the nerve by "compression posture" lasts less than $6 \mathrm{~h}$, the block of nerve conduction is rapidly reversible, while if the ischemic period persists beyond $8 \mathrm{~h}$, the recovery requires weeks. It could be related to a demyelinating block caused by direct pressure on perineum [6].

The pudendal neuralgia, caused by entrapment and compression of the pudendal nerve, is characterized by severe, sharp pain along the course of the pudendal nerve [7], genital numbness, erectile dysfunction (ED), and impotence [2,8].

Once afflicted, the cyclists are inclined to relapses; awareness of the problem could improve the adherence to prevention and therapeutic strategies [9]. Cyclists should pay close attention to any early warning symptoms and signs, such as pain, tingling, or numbness of 
the penis and/or perineum. Even in the absence of such symptoms, cyclists should follow several pieces of advice.

Very few robust trials are present in the current literature, several of them not recent, despite the actuality of the disorder. This disabling condition related to musculoskeletal and neuropathic disorders often dictates to stop playing this sport, and this advice needs to be extended. New research could make substantial changes in the diagnostic path, and in taking charge. The therapeutically proposed solutions should not be directed to the suspension of cycling, but to timely treatment to achieve a complete recovery, rehabilitation from symptoms, and functional ergonomics.

The systematic review aims to provide an overview of the diagnostic methods, preventive strategies, and therapeutic approaches for the cyclists suffering from pudendal neuropathy. The study defines a guide in delineating a diagnostic and therapeutic protocol using the best current strategies. Moreover, an update on the topicality of this disorder and on the disabling condition in those who practice this sport could increase the attention to the problem to obtain a dedicated field of interest and prevent the disorder.

\section{Methods}

\subsection{Search Strategy}

A systematic literature search on the preventive strategies and therapeutic approaches for the cyclists suffering from pudendal neuropathy was carried out. Pubmed, EMBASE, the Cochrane Library, and Scopus Web of Science were searched. The review was conducted from 1 May 2020 to 2 April 2021.

\subsection{Selection Criteria and Data Extraction}

Two independent reviewers (R.C. and M.V.) screened articles by title and abstract for the following key terms: "Bicycling" OR "Bike" OR "Cyclists" AND "Neuropathy" OR "Pudendal Nerve" OR "Pudendal Neuralgia" OR "Perineum". We included original articles (case reports, case series, observational and prospective studies) in English on prevention and therapeutic strategies for pudendal neuropathy in healthy cyclists. Only published data were included. We excluded animal studies and studies with participants who had no peripheral perineum neuropathy and those different from cyclists. We also excluded all duplicate studies.

The systematic review was executed according to the PRISMA checklist [10] and the PICOS criteria [11] (population, intervention, comparison, outcome, and study design). As shown in Table 1, the participants were cyclists, and the interventions were based on prevention and rehabilitative or pharmacologic treatment. The comparator could be any comparator, and the outcomes included clinical assessments, diagnostic scales, and nerve conduction studies, as well as radiologic imaging. 
Table 1. Characteristics and outcomes of studies included in the systematic review.

\begin{tabular}{|c|c|c|c|c|c|c|c|}
\hline Authors & Study Design & Participants & $\begin{array}{c}\text { Beginning of } \\
\text { Symptomatology }\end{array}$ & Symptoms & Diagnosis & Treatment & Outcomes \\
\hline Andersen 1997 [6] & Observational study & $\begin{array}{c}160 \mathrm{~cm} \\
37.5 \pm 10.9 \mathrm{y}\end{array}$ & After $540 \mathrm{~km}$ & $\begin{array}{l}\text { Penile numbness or hypaesthesia, } \\
\text { ED after the tour for } h \text { to } m \text {. }\end{array}$ & Clinical diagnosis & $\begin{array}{l}\text { Besides changing the body position on } \\
\text { the bike, restricting the training } \\
\text { intensity and taking ample pauses may } \\
\text { also be necessary in prolonged and } \\
\text { vigorous bicycle riding to prevent } \\
\text { damage to peripheral nerves. }\end{array}$ & $\begin{array}{l}22 \% \text { reported numbness, } 13 \% \\
\text { impotence. It lasted for more } \\
\text { than } 1 \text { week in } 11 \text {, and for more } \\
\text { than } 1 \text { month in } 3 \text { participants. }\end{array}$ \\
\hline Bond 1975 [9] & Case series & $22 \mathrm{c}$ & After 40 miles or more & $\begin{array}{l}\text { Numb penis during and after } \\
\text { a ride. }\end{array}$ & Clinical diagnosis & $\begin{array}{l}\text { Tilting the peak of the saddle } \\
\text { downward, shifting their weight on } \\
\text { the saddle, stopping to rest, and } \\
\text { shifting to a higher gear and standing } \\
\text { up to pedal. }\end{array}$ & $\begin{array}{l}\text { It is a benign disorder with } \\
\text { spontaneous resolution usually } \\
\text { occurring overnight. }\end{array}$ \\
\hline Calvillo 2000 [4] & Case report & $\begin{array}{l}1 \mathrm{c}, \\
52 \mathrm{y}\end{array}$ & After $10 \mathrm{~min}$ & Anoperineal pain from $2 \mathrm{y}$. & СТ & $\begin{array}{c}\text { Gabapentin } 300 \mathrm{mg} \text { daily for } 6 \text { months } \\
\text { without any success. } \\
\text { Diagnostic bilateral pudendal nerve } \\
\text { block under CT guidance, injecting } 4 \\
\text { mL of lidocaine with } 1 \mathrm{~mL} \text { of } \\
\text { triamcinolone }(40 \mathrm{mg})\end{array}$ & $\begin{array}{l}\text { The use of } \mathrm{CT} \text { to guide the } \\
\text { procedure allowed precision in } \\
\text { performing the procedure and in } \\
\text { making a differential diagnosis. }\end{array}$ \\
\hline De Rose 2001 [12] & Case report & $\begin{array}{l}2 \mathrm{c}, \\
31.5 \mathrm{y}\end{array}$ & $\begin{array}{l}1 \mathrm{c}: \text { immediately after } \\
\text { a trauma }\end{array}$ & ED for $2 \mathrm{~m}$. & $\begin{array}{l}\text { Intracorporeal blood gas } \\
\text { analysis, color Doppler } \\
\text { ultrasonography, and } \\
\text { selective pudendal } \\
\text { arteriography }\end{array}$ & $\begin{array}{l}\text { Embolization of the fistula with } \\
\text { gelatin sponge }\end{array}$ & $\begin{array}{l}\text { Cycling should be considered a } \\
\text { possible risk factor for arterial } \\
\text { priapism as it is for urethritis, } \\
\text { prostatitis, hematuria, testicular } \\
\text { torsion, scrotal and penile } \\
\text { numbness, and } \\
\text { erectile dysfunction. }\end{array}$ \\
\hline Desai 1989 [13] & Case report & $\begin{array}{l}1 \mathrm{c}, \\
27 \mathrm{y}\end{array}$ & After $32 \mathrm{~km}$ bicycle race & $\begin{array}{l}\text { Ipoaesthesia, loss of erections for } \\
\text { about three weeks. }\end{array}$ & Doppler, EMG & - & Description of the case report. \\
\hline Dettori 2004 [14] & Prospective study & $463 c$ & After $320 \mathrm{~km}$ race & $\begin{array}{l}\text { Perineal numbness during the } \\
\text { ride, erectile dysfunction for } 8 \mathrm{~m} \text {. }\end{array}$ & $\begin{array}{l}\text { International Index of } \\
\text { Erectile Function }\end{array}$ & $\begin{array}{l}\text { Cyclists on a long-distance ride may be } \\
\text { able to decrease the risk of erectile } \\
\text { dysfunction by riding a road bicycle } \\
\text { instead of a mountain bicycle, keeping } \\
\text { handlebar height lower than saddle } \\
\text { height, and using a saddle without a } \\
\text { cutout if perineal numbness } \\
\text { is experienced. }\end{array}$ & $\begin{array}{l}\text { Associations between erectile } \\
\text { dysfunction risk and riders. }\end{array}$ \\
\hline Durante 2010 [8] & Case report & $\begin{array}{l}1 \mathrm{c}, \\
41 \mathrm{y}\end{array}$ & $\begin{array}{l}\text { After } 6-11 \mathrm{~h} \text { per week, } \\
3 \text { days a week of training }\end{array}$ & $\begin{array}{l}\text { Penis pain } 12-24 \mathrm{~h} \text { after long } \\
\text { distance cycling and pain after } \\
\text { sexual intercourse. Hyperalgesia } \\
\text { was found during palpation of the } \\
\text { lesser sciatic notch and the } \\
\text { obturator internus muscle. }\end{array}$ & Pain intensity scale & $\begin{array}{l}\text { Treated twice a week for } 4 \mathrm{w} \text { with ART } \\
\text { obturator internus muscle protocol. }\end{array}$ & $\begin{array}{l}\text { Diagnosis and treatment of } \\
\text { pudendal nerve entrapment. }\end{array}$ \\
\hline Goodson 1981 [3] & Case report & $\begin{array}{l}1 \mathrm{c}, \\
46 \mathrm{y}\end{array}$ & After a 2-day, 180-mile ride & $\begin{array}{l}\text { Diminished sensitivity to light } \\
\text { touch along the penile shaft, } \\
\text { numbness for } 4 \mathrm{w} \text {. }\end{array}$ & Clinical assessment & $\begin{array}{l}\text { Added seat padding or more } \\
\text { downward seat slanting is a } \\
\text { therapeutic recommendation. }\end{array}$ & $\begin{array}{l}\text { Pudendal compression between } \\
\text { bike seat and pubic symphysis } \\
\text { can cause impairment of } \\
\text { sexual response. }\end{array}$ \\
\hline
\end{tabular}


Table 1. Cont.

\begin{tabular}{|c|c|c|c|c|c|c|c|}
\hline Authors & Study Design & Participants & $\begin{array}{c}\text { Beginning of } \\
\text { Symptomatology }\end{array}$ & Symptoms & Diagnosis & Treatment & Outcomes \\
\hline Guess 2006 [15] & Observational study & $\begin{array}{l}48 \mathrm{c}, \\
22 \mathrm{hc} \\
33 \mathrm{y}\end{array}$ & $\begin{array}{l}\text { Average of } 28.3 \pm 19.7 \\
\text { miles/d, } 3.8 \pm 1.5 \mathrm{~d} / \mathrm{w}, \text { for } \\
\text { an average of } 2.1 \pm 1.8 \mathrm{~h} / \mathrm{r}\end{array}$ & Normal sexual function. & VTs, SPEQ, FSDS & - & $\begin{array}{l}\text { Increasing VTs at the clitoris, } \\
\text { anterior vagina, and urethra } \\
\text { were associated with age. In } \\
\text { bicyclists, there were no } \\
\text { correlations between VTs and } \\
\text { miles biked per week, duration } \\
\text { of riding, or BMI }\end{array}$ \\
\hline Guess 2011 [16] & Case series & $\begin{array}{c}48 \mathrm{c} \\
35.98 \pm 6.90\end{array}$ & $99.24 \pm 74.11$ miles $/ \mathrm{w}$ & $\begin{array}{l}\text { Pain, numbness, and edema of } \\
\text { pelvic floor structures. }\end{array}$ & VTs & - & $\begin{array}{c}\text { Cut-out and narrower saddles } \\
\text { negatively affect saddle } \\
\text { pressures in female cyclists }\end{array}$ \\
\hline $\begin{array}{c}\text { Oberpenning } \\
\text { [2] }\end{array}$ & Case reports & $2 \mathrm{c}$ & - & Numbness for 4-6 w. & $\begin{array}{c}\text { Sonography of abdomen, } \\
\text { prostate and testes, MRI of } \\
\text { pelvis and lumbar spine, } \\
\text { Doppler sonography }\end{array}$ & $\begin{array}{c}\text { The symptoms in the } 2 \text { patients } \\
\text { spontaneously resolved after } 4 \text { and } \\
7 \text { weeks, respectively, without specific } \\
\text { medical therapy. }\end{array}$ & $\begin{array}{l}\text { Description of intermittent } \\
\text { genital hypesthesia that } \\
\text { occurred in cyclists after } \\
\text { long-term bicycle riding. }\end{array}$ \\
\hline Partin 2012 [17] & Observational study & $\begin{array}{c}c_{1} \\
22 \text { runners }\end{array}$ & $>10$ miles $/ \mathrm{w}$ & $\begin{array}{c}62 \% \text { genital numbness, tingling or } \\
\text { pain }\end{array}$ & Clinical diagnosis, VTs & Modifying the handlebar level & $\begin{array}{l}\text { Correlation between bicycle } \\
\text { set-up and neurological } \\
\text { compromise in women cyclists }\end{array}$ \\
\hline Ricchiuti 1999 [18] & Case report & $\begin{array}{r}1 \mathrm{c}, \\
44 \mathrm{y}\end{array}$ & $3000 \mathrm{~m} / \mathrm{y}$ & $\mathrm{ED}$, numbness & $\begin{array}{l}\text { EMG evidence of bilateral } \\
\text { pudendal nerve injury. }\end{array}$ & $\begin{array}{l}\text { C decreased bicycling from } 3000 \text { to } \\
\text { approximately } 1500 \text { miles per year due } \\
\text { to the persistent symptoms. }\end{array}$ & $\begin{array}{l}\text { This condition may be associated } \\
\text { with male ED if the penile blood } \\
\text { supply is compromised. }\end{array}$ \\
\hline Silbert 1991 [5] & Case reports & $2 c$ & $\begin{array}{l}\text { A: after switching to } \\
\text { triathlon bars and a narrow } \\
\text { firm seat. } \\
\text { B: after being hit by a car } \\
\text { and sustained a } \\
\text { perineal injury. }\end{array}$ & Penile numbness & Clinical assessment & $\begin{array}{l}\text { A: Symptoms resolved after the subject } \\
\text { returned to traditional drop bars and a } \\
\text { softer saddle. } \\
\text { B: After a period of not cycling, his } \\
\text { symptoms resolved completely. }\end{array}$ & $\begin{array}{l}\text { Pudendal nerve pressure } \\
\text { neuropathy can result from } \\
\text { prolonged cycling, particularly } \\
\text { when using a poor } \\
\text { riding technique. }\end{array}$ \\
\hline Solomon 1987 [19] & Case report & $\begin{array}{c}1 \mathrm{c}, \\
55 \mathrm{y} 11\end{array}$ & $\begin{array}{l}\text { After beginning to use a } \\
\text { stationary bike. }\end{array}$ & Penile numbness and ED & Clinical diagnosis & Resolved once he stopped riding. & $\begin{array}{l}\text { A relationship between sexual } \\
\text { dysfunction and bicycling may } \\
\text { be more common than } \\
\text { formerly suspected. }\end{array}$ \\
\hline
\end{tabular}

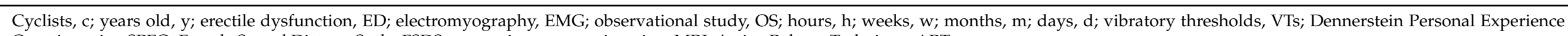
Questionnaire, SPEQ; Female Sexual Distress Scale, FSDS; magnetic resonance imaging, MRI; Active Release Technique, ART. 


\section{Result}

\subsection{Description of the Studies}

From 1975 to 2021, the database search identified 14,602 articles. After the titles and abstracts were screened, the reviewers analyzed 41 full texts. Additionally, the reference lists of relevant articles were screened for any other eligible articles to include for review. The studies' eligibility was assessed independently.

Twenty-six articles were excluded for the following reasons: 9 did not use the English language, 17 examined different neurological disorders from pudendal neuropathy. Figure 1 shows the number of studies produced at each stage of the search. A total of 15 articles were considered eligible for inclusion (Figure 1 and Table 1).

Records identified through database searching $(\mathrm{n}=14.602)$
Additional records identified through other sources $(\mathrm{n}=9)$

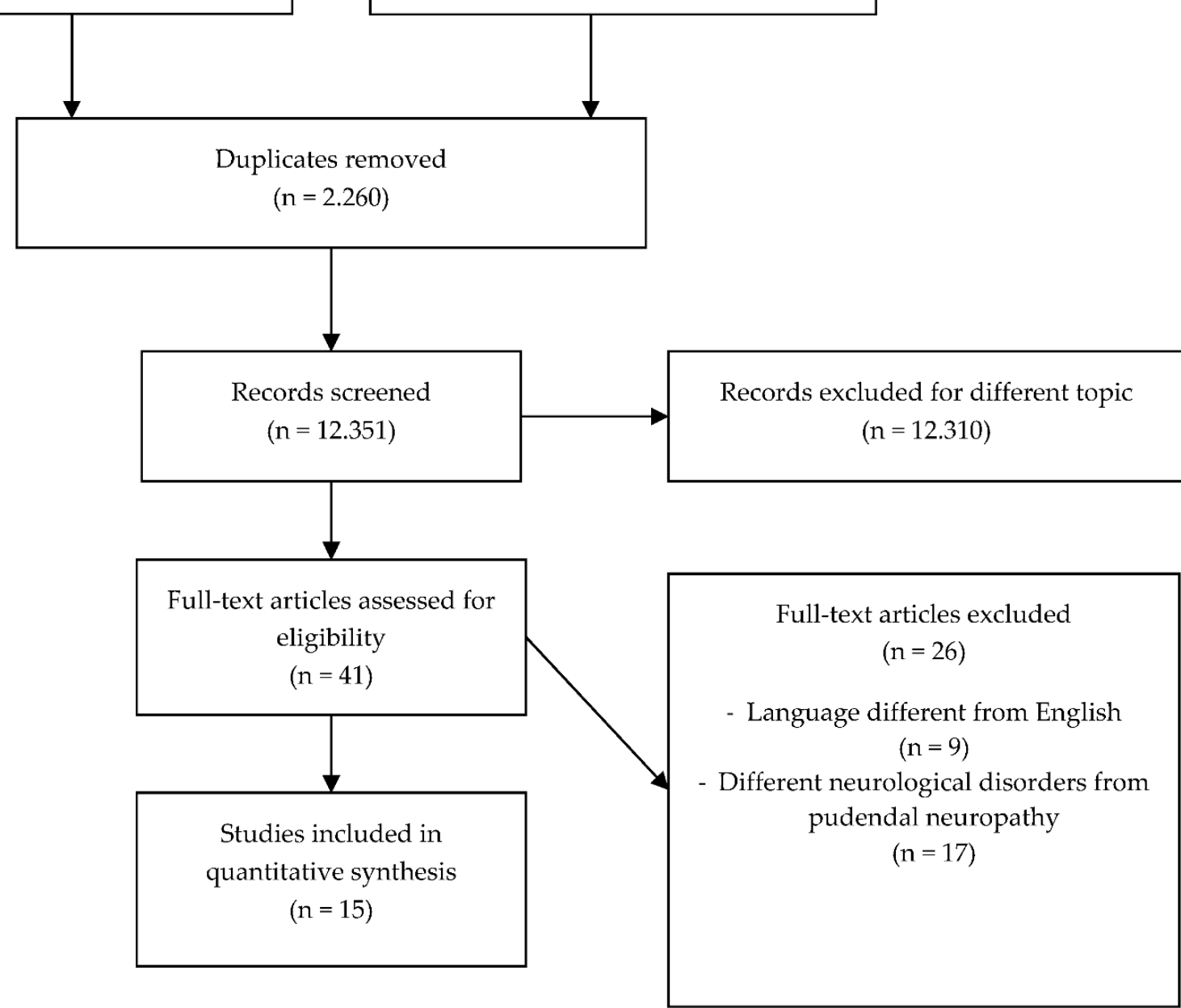

Figure 1. Flowchart of the process of literature search and extraction of studies meeting the inclusion criteria.

\subsection{Variations of Experimental Conditions across the Studies}

The methods used in each of the 15 selected articles for the prevention and treatment of peripheral neuropathy of perineum in cyclists were described. The study groups were homogeneous for relevant general clinical features, such as sport practice and localization of the lesion, but not for clinical presentation, duration of symptoms, miles before starting of symptoms, types of diagnostic measures, severity of symptoms, and therapy (Table 1). 


\subsection{Summary of Findings}

\subsubsection{Diagnostic Examination}

The systematic review showed preventive and therapeutic approaches for peripheral neuropathy in cyclists and all the diagnostic methods used in the current literature.

Clinical evaluation related to the sport is considered enough for the diagnosis of pudendal neuropathy due to cycling $[3,5,6,9,13,17,19]$.

Several scales and instrumental diagnostics were used to diagnose the severity of the disorders: Pain Intensity Scale [8], International Index of Erectile Function [14], Dennerstein Personal Experience Questionnaire (SPEQ) [15], Female Sexual Distress Scale (FSDS) [15]. The diagnostic methods included nerve conduction studies and electromyography $[13,18]$, radiologic diagnosis with ultrasonography and doppler waveforms $[2,12,13]$, computed tomography [4], magnetic resonance imaging (MRI) [2], and diagnostic arteriography [12].

\subsubsection{Bike Elements Related to Peripheral Neuropathy}

The area of contact between the bicyclist and the bike is the cause of nerve compression. Comfortable characteristics of the bicycle and practical recommendations are shown in Table 2.

Bike

Bicycle characteristics associated with an increased risk of erectile dysfunction included a mountain bicycle compared to a road bicycle [14].

Seat

Prolonged sitting on a hard, narrow, and upward-tilted seat contributes to the development of impotence [3]. The narrow saddle is associated with a significant reduction in penile blood flow and could be a source of blunt perineal trauma with consequent erectile dysfunction [20]. The upward-tilted seat places greater pressure on the perineum [21].

Table 2. Comfortable characteristics of the bicycle and practical recommendations.

\begin{tabular}{ccc}
\hline Practical Recommendations & Characteristics of Bike Parts and Practical Strategies & References \\
\hline \multirow{2}{*}{ Bicycle parts: seat } & Soft, wide & {$[5]$} \\
\cline { 2 - 3 } & Horizontal and not inclined seat & {$[23,24]$} \\
\cline { 2 - 3 } Bicycle parts: handlebars & Sbsent or flexible nose on the saddle & {$[14,16,22]$} \\
\hline Sportswear & Sandlebar height lower than the saddle & {$[14]$} \\
\hline Rest & Avoiding triathlon bars & {$[5]$} \\
\hline Advice & Padded biking shorts & {$[25]$} \\
\hline \multirow{2}{*}{ Rehabilitation program } & Reduction of sport activity & {$[2,5,12,20]$} \\
\cline { 2 - 3 } & Shifting to a higher gear, and standing on the pedals periodically & {$[9,26]$} \\
\hline
\end{tabular}

The use of cut-out saddles could increase the pressure along the area of the pudendal nerves and vessels [22], with a higher risk of ED compared with a traditional saddle shape, particularly in those who had perineal numbness [14].

According to Carpes et al. [23], the seat pressure was not different between men and women. Using plain saddles, the men's average seat pressure increased as the workload increased. Using a holed saddle, the mean pressure increased as the workload increased 
both in men and in women [23]. This study [23] was not included in the systematic review because the tested cyclists did not report any symptoms.

Handlebars

A height of the handlebars parallel with or higher than the saddle could increase the risk of pudendal neuropathy compared to handlebar height lower than the saddle [14]. A height of handlebars lower than the saddle could increase vibratory thresholds and cause decreased genital sensation in the anterior vagina and labia [17].

The use of triathlon bars causes cyclists to move forwards the body with an excessive pressure on the perineum and compression of the pudendal nerve [5].

\subsection{Sex Influence}

Most of the articles analyzed nerve impairment $[2-6,8,14]$ and ischemic neuropathy condition $[9,12,13,18,19]$ in men.

Only a few articles analyzed the corresponding conditions in women [15-17]. There is an association between bicycling and decreased genital sensation in competitive women bicyclists, even if negative effects on sexual function and quality of life were not apparent in young, healthy premenopausal cyclists [15]. A correlation between bicycle set-up and neurological impairment was considered in female cyclists [17]. A study suggests that cut-out and narrow saddles could negatively affect saddle pressures in female cyclists [16]. An association was highlighted between bicycling and decreased genital sensation in competitive women bicyclists [15]. Correcting modifiable risks factors for pelvic floor damage may serve as the most important next step in enhancing riding safety in women cyclists [17].

\section{Discussion}

This systematic review gives an overview of all diagnostic methods used and preventive and therapeutic strategies essential for cyclists to avoid pudendal neuropathy. The study describes the musculoskeletal and neuropathic disorders caused by careless physical exercise contrary to what is generally reported in the literature, namely, the role of physical exercise to prevent and treat musculoskeletal disorders. The role of correct training in the musculoskeletal and neuropathic disorders is essential to avoid traumatic and overuse-related symptoms. The execution of the athletic gesture should improve performance and not cause related pathologies.

\subsection{Diagnostic Approach}

Pudendal neuralgia is a diagnosis of exclusion. The multidisciplinary team of Nantes, France and Francophone Perineal Electrophysiology members in 2008 drew up the diagnostic criteria [27].

Clinical examination supports the definitive diagnosis $[3,5,6,9,13,17,19]$.

Several scales were used to diagnose the severity of the disorders. Durante et al. [8] used the Pain Intensity Scale, Dettori et al. [14] used the International Index of Erectile Function [28], Guess et al. [15] used the Dennerstein Personal Experience Questionnaire (SPEQ) [29] and the Female Sexual Distress Scale (FSDS) [30].

Four studies assessed the neuropathy compression with radiologic imaging $[2,4,12,13]$. Ricchiuti et al. [18] performed the electromyography that evidenced a bilateral pudendal nerve injury. Guess et al. $[15,16]$ determined the genital vibratory thresholds (VTs), but they did not find any correlations between VTs and miles biked per week, duration of riding, or BMI (body mass index) of cyclists [15]. Partin et al. [17] described a significative association between increased VTs and decreased genital sensation in the anterior vagina and labia. 


\subsection{Cautions to Avoid Peripheral Neuropathy}

Several articles highlight a spontaneous resolution with rest $[2,5,19]$ and reduction of sport activity [18], modifications of bike components [3,6,9,14], and following a rehabilitation program $[8,23,24]$.

The characteristics of the bike could influence the symptomatology related to pudendal nerve compression. Dettori et al. [14] suggested to choose a road bicycle instead of a mountain bicycle. Specific size and shape of saddle, handlebars, and the duration of rest period affect the onset and the severity of the compression neuropathy. These limitations of activity are often less accepted by athletes [6].

\subsubsection{Breaks and Rest}

The changes of the riding position during the training can alleviate symptoms [5,9]. During the training, frequent breaks, shifting to a higher gear, and standing on the pedals periodically can take pressure off the genital area $[9,26]$. Several authors recommend a period of rest during the race $[3,9,26]$, exactly $20-30 \mathrm{~s}$ of rest every $20 \mathrm{~min}[23,24]$.

Reduction of activity [18] or rest [19] can reduce the symptoms after their onset.

\subsubsection{Seat Arrangement}

Bicycles should be fitted properly, and the saddle should be adjusted to the proper height and angle to avoid nerve compression. The US Army equestrian saddle has a slot in the center so that there is no pressure against the penis [9]. The therapeutic recommendations include a greater and wider seat padding, an absent or flexible nose on the saddle, a gel saddle, a more downward seat position or slighter tilt downwards to avoid anterior compression $[3,9,23,24]$. The seated weight should set down on the ischial tuberosities. The seated height should permit a slight flexion during pedaling at the lowest point of the pedal. Reducing the pressure on the perineum appears to be the solution, because in the cyclists the repetitive sliding of the fascia lata could decrease penile perfusion [25].

A saddle without a cut-out could help in the cases of perineal numbness [14].

Alongside wide and padded saddles, padded biking shorts increase comfort and protect the perineal soft tissue more than the other seat designs [26].

\subsubsection{Handlebars}

In addition to adjusting the seat, cyclists should attend to the handlebar position [31]. Maintaining height of the handlebar lower than the saddle could prevent nerve compression [14].

\subsection{Rehabilitation and Physical Exercises}

A specific program of exercises could help weight loss if necessary as overweight could worsen nerve compression. Specific exercises are important for making adjustments in technique and improving the body posture to a more upright position. Stretches and rest for 3-10 days often promote recovery [23,24].

Durante et al. [8] presented the Active Release Technique (ART) for the treatment of symptoms related to pudendal nerve entrapment [32]. The practitioners apply tension to muscles and the patients actively contract and shorten the muscles and then stretch and tense them [32].

\subsection{Invasive Treatment}

Treatment is related to the degree of discomfort and symptoms. Conservative measures are often enough. In cases of severe, intractable discomfort and dysfunction, more aggressive and invasive treatment is necessary.

Calvillo et al. [4] used a CT-guided pudendal nerve block to temporarily relieve longstanding perineal and scrotal pain in a cyclist. Surgical decompression of the pudendal nerve could be a therapeutic option in cyclists for whom there was only temporary relief after the nerve block. 
Several cases of high-flow priapism as a result of acute bilateral perineal trauma sustained during bicycling have been reported $[12,33]$. They were treated successfully with percutaneous arterial embolization [12,33].

\subsection{Pharmacological Treatment}

Symptomatic drugs might have beneficial effects, anti-inflammatory and nerve pain medications or vasodilator drugs may be used in cases of ischemic neuropathy.

Gabapentin $300 \mathrm{mg}$ daily for 6 months did not yield any success [4].

For the pudendal nerve block, under CT guidance, injection of $4 \mathrm{~mL}$ of lidocaine with $1 \mathrm{~mL}$ of triamcinolone $(40 \mathrm{mg}$ ) relieves the symptoms for a longer period of time [4].

\section{Study Limitations}

In this systematic review, most studies are of low to moderate quality. Several studies are case reports or have very small sample sizes, leading to questions regarding their statistical power.

\section{Conclusions}

This research highlights all the preventive and therapeutic strategies towards obtaining a guide for those who treat, train, and support cyclists with pudendal neuropathy. Increased attention to the execution of the athletic gesture is essential to obtaining good sport results, and especially to avoiding the possibility of training becoming the cause of musculoskeletal and neuropathic disorders.

New bicycle designs pay attention to preserving the perineum, avoiding nerve compression, reducing perineal pressure, and preventing impingement of the pudendal nerve. However, nerve compression could be present, and its diagnosis and treatment are necessary.

The symptomatology related to pudendal neuropathy could affect experienced and novice cyclists. Cyclists could develop a less severe disorder by maintaining better posture on the bike and adhering to the advice on preventive measures. A conservative treatment permits the recovery, rarely requiring invasive treatment.

Although the studies included in the systematic review on this topic present a moderate or low level of evidence, they could lead to new original and innovative leaps in the study the potential problem in more detail. Despite the range of tools available, robust trials are lacking, and the diagnostic and therapeutic approaches are often different. More research is needed to determine the measurements of treatment adherence and costeffectiveness, the best diagnostic methodologies, and preventive and therapeutic strategies, to delineate a definitive diagnostic and therapeutic protocol, including preventive tools, such as improved bike models and new bike elements.

Funding: This research received no external funding.

Institutional Review Board Statement: Not applicable.

Informed Consent Statement: Not applicable.

Data Availability Statement: Not applicable.

Conflicts of Interest: The authors declare no conflict of interest.

\section{References}

1. Leibovitch, I.; Mor, Y. The vicious cycling: Bicycling related urogentital disorders. Eur. Urol. 2005, 47, 277-287. [CrossRef]

2. Oberpenning, F.; Roth, S.; Leusmann, D.; Van Ahlen, H.; Hertle, L. The Alcock Syndrome: Temporary Penile Insensitivity Due to Compression of the Pudendal Nerve within the Alcock Canal. J. Urol. 1994, 151, 423-425. [CrossRef]

3. Goodson, J.D. Pudendal Neuritis from Biking. N. Engl. J. Med. 1981, 304, 365. [CrossRef]

4. Calvillo, O. Computed tomography-guided pudendal nerve block. A new diagnostic approach to long-term anoperineal pain: A report of two cases. Reg. Anesth. Pain Med. 2000, 25, 420-423. [CrossRef] [PubMed]

5. Silbert, P.L.; Dunne, J.W.; Edis, R.H.; Stewart-Wynne, E.G. Bicycling induced pudendal nerve pressure neuropathy. Clin. Exp. Neurol. 1991, 28, 191-196. 
6. Andersen, K.V.; Bovim, G. Impotence and nerve entrapment in long distance amateur cyclists. Acta Neurol. Scand. 1997, 95, 233-240. [CrossRef] [PubMed]

7. Benson, J.T.; Griffis, K. Pudendal neuralgia, a sever pain syndrome. Am. J. Obst. Gyn. 2005, 192, 1663-1668. [CrossRef]

8. Durante, J.A.; MacIntyre, I.G. Pudendal nerve entrapment in an Ironman athlete: A case report. J. Can. Chiropr. Assoc. 2010, 54, 276-281.

9. Bond, R.E. Distance Bicycling May Cause Ischemic Neuropathy of Penis. Physician Sportsmed. 1975, 3, 54-56. [CrossRef]

10. Shamseer, L.; Moher, D.; Clarke, M.; Ghersi, D.; Liberati, A.; Petticrew, M.; Shekelle, P.; Stewart, L.A. Preferred reporting items for systematic review and meta-analysis protocols (PRISMA-P) 2015: Elaboration and explanation. BMJ Br. Med. J. 2015, 349 , g7647. [CrossRef]

11. Higgins, J.P.; Altman, D.G.; Gøtzsche, P.C.; Jüni, P.; Moher, D.; Oxman, A.D.; Savović, J.; Schulz, K.F.; Weeks, L.; Sterne, J.A. The Cochrane Collaboration's tool for assessing risk of bias in randomised trials. Br. Med. J. 2011, 343, 889-893. [CrossRef] [PubMed]

12. De Rose, A.F.; Giglio, M.; De Caro, G.; Corbu, C.; Traverso, P.; Carmignani, G. Arterial priapism and cycling: A new worrisome reality? Urology 2001, 58, 462. [CrossRef]

13. Desai, K.M.; Gingell, J.C. Hazards of long distance cycling. BMJ 1989, 298, 1072-1073. [CrossRef] [PubMed]

14. Dettori, J.R.; Koepsell, T.D.; Cummings, P.; Corman, J.M. Erectile dysfunction after a long-distance cycling event: Associations with bicycle characteristics. J. Urol. 2004, 172, 637-641. [CrossRef]

15. Guess, M.K.; Connell, K.; Schrader, S.; Reutman, S.; Wang, A.; Lacombe, J.; Toennis, C.; Lowe, B.; Melman, A.; Mikhail, M. Original research-Women's sexual health: Genital Sensation and Sexual Function in Women Bicyclists and Runners: Are Your Feet Safer than Your Seat? J. Sex. Med. 2006, 3, 1018-1027. [CrossRef]

16. Guess, M.K.; Partin, S.N.; Schrader, S.; Lowe, B.; Lacombe, J.; Reutman, S.; Wang, A.; Toennis, C.; Melman, A.; Mikhail, M.; et al. Women's bike seats: A pressing matter for competitive female cyclists. J. Sex. Med. 2011, 8, 3144-3153. [CrossRef] [PubMed]

17. Partin, S.N.; Connell, K.A.; Schrader, S.; Lacombe, J.; Lowe, B.; Sweeney, A.; Reutman, S.; Wang, A.; Toennis, C.; Melman, A.; et al. The Bar Sinister: Does Handlebar Level Damage the Pelvic Floor in Female Cyclists? J. Sex. Med. 2012, 9, 1367-1373. [CrossRef]

18. Ricchiuti, V.S.; Haas, C.A.; Seftel, A.D.; Chelimsky, T.; Goldstein, I. Pudendal nerve injury associated with avid bicycling. J. Urol. 1999, 162, 2099-2100. [CrossRef]

19. Solomon, S.; Cappa, K.G. Impotence and bicycling. Postgrad. Med. 1987, 81, 99-102. [CrossRef]

20. Jeong, S.-J.; Park, K.; Moon, J.-D.; Ryu, S.B. Bicycle saddle shape affects penile blood flow. Int. J. Impot. Res. 2002, 14, 513-517. [CrossRef]

21. McDonald, D.I. Is there life after genital numbness? N. Z. Med. J. 1987, 100, 465. [PubMed]

22. Ronado, R.; Squadrone, R.; Sacchi, M.; Marzegan, A. Saddle pressure distribution in cycling: Comparison of saddles of different design and materials. In Proceedings of the 20 International Symposium on Biomechanics in Sports (ISBS 2002), Caceres, Spain, 1-5 July 2002.

23. Carpes, F.P.; Dagnese, F.; Kleinpaul, J.F.; Martins, E.D.A.; Mota, C.B. Effects of Workload on Seat Pressure While Cycling with Two Different Saddles. J. Sex. Med. 2009, 6, 2728-2735. [CrossRef] [PubMed]

24. Gemery, J.M.; Nangia, A.K.; Mamourian, A.C.; Reid, S.K. Digital three-dimensional modelling of the male pelvis and bicycle seats: Impact of rider position and seat design on potential penile hypoxia and erectile dysfunction. BJU Int. 2007, 99, 135-140. [CrossRef] [PubMed]

25. Mellion, M.B. Common Cycling Injuries. Sports Med. 1991, 11, 52-70. [CrossRef] [PubMed]

26. Schwarzer, U.; Sommer, F.; Klotz, T.; Cremer, C.; Engelmann, U. Cycling and Penile Oxygen Pressure: The Type of Saddle Matters. Eur. Urol. 2002, 41, 139-143. [CrossRef]

27. Labat, J.-J.; Riant, T.; Robert, R.; Amarenco, G.; Lefaucheur, J.-P.; Rigaud, J. Diagnostic criteria for pudendal neuralgia by pudendal nerve entrapment (Nantes criteria). Neurourol. Urodyn. 2008, 27, 306-310. [CrossRef] [PubMed]

28. Rosen, R.C.; Riley, A.; Wagner, G.; Osterloh, I.H.; Kirkpatrick, J.; Mishra, A. The international index of erectile function (IIEF): A multidimensional scale for assessment of erectile dysfunction. Urology 1997, 49, 822-830. [CrossRef]

29. Dennerstein, L.; Anderson-Hunt, M.; Dudley, E. Evaluation of a short scale to assess female sexual functioning. J. Sex Marital Ther. 2002, 28, 389-397. [CrossRef]

30. Derogatis, L.R.; Rosen, R.; Leiblum, S.; Burnett, A.; Heiman, J. The Female Sexual Distress Scale (FSDS): Initial Validation of a Standardized Scale for Assessment of Sexually Related Personal Distress in Women. J. Sex Marital Ther. 2002, 28, 317-330. [CrossRef]

31. Gardiner, K.M. More on bicycle neuropathies. N. Engl. J. Med. 1975, 292, 1245.

32. Leahy, M. Active Release Techniques ${ }^{\circledR}$ Soft Tissue. Manag. Syst. Lower Extrem. 2007, 188-189.

33. Golash, A.; Gray, R.; Ruttley, M.S.T.; Jenkins, B.J. Traumatic priapism: An unusual cycling injury. Br. J. Sports Med. 2000, 34, 310-311. [CrossRef] [PubMed] 